\title{
Pengajaran Bahasa Inggris Komunikatif Berbasis Budaya kepada Sekaa Teruna-Teruni Desa Tenganan Dauh Tukad
}

\author{
Ni Nyoman Kertiasih ${ }^{1 凶}$, I Nyoman Kardana ${ }^{2}$, Anak Agung Istri Manik Warmadewi ${ }^{3}$, Ni Luh Gede Mas \\ Antartika Dewi Artana ${ }^{4}$ \\ Sastra Inggris, Universitas Warmadewa, Indonesia ${ }^{1,2,3,4}$ \\ Email: nn.kertiasih@gmail.com ${ }^{1}$, ikardana@yahoo.com² ${ }^{2}$ manikwarmadewi@gmail.com ${ }^{3}$, \\ antartikadewi62@gmail.com ${ }^{4}$
}

\begin{abstract}
Abstrak
Sekaaa teruna-teruni adalah generasi penerus yang akan mewarisi budaya yang ada. Pengetahuan umum tentang budaya akan sangat penting, begitu juga bagi generasi muda di Desa Tenganan Dauh Tukad. Desa ini merupakan desa wisata yang dikenal dengan budaya yang unik. Pariwisata dan budaya merupakan komponen fundamental penyokong ekonomi desa ini, tentunya kemampuan berbahasa Inggris sangat diperlukan. Bahasa merupakan komponen utama dalam komunikasi yang diperlukan dalam bidang pariwisata dan budaya yang unik dijadikan daya tarik utama wisata di desa ini. Pengabdian ini berkofus pada pembelajaran Bahasa Inggris berbasis Budaya yang ditujukan untuk generasi muda atau sekaa teruna-teruni di Desa Tenganan Dauh Tukad. Metode pembelajaran yang digunakan adalah metode pembelajaran komunikatif. Selain itu kegiatan ini juga didukung dengan video pembelajaran, power point, dan penjelasan materi. Hasil dari pengabdian ini adalah peserta yang kurang percaya diri dan kurang paham akan Bahasa Inggris menjadi percaya diri dan mampu menyampaikan penjelasan mengenai kebudayaan yang dimiliki dalam Bahasa Inggris dengan baik. Dengan pengajaran bahasa Inggris yang komuikatif rasa percaya diri peserta dapat ditingkatkan sehingga tidak takut salah dalam menggunakan Bahasa Inggris saat berhadapan dengan wisatawan secara langsung nantinya.
\end{abstract}

Kata kunci: sekaa teruna-teruni, pembelajaran Bahasa Inggris budaya

Abstract

Sekaa teruna-teruni is a young generation that will inherit existing culture. General knowledge of the culture will be necessary and for the young generation in Tenganan Dauh Tukad. This village is a tourist village known for its unique culture. Tourism and culture are fundamental components of economic ancillary, of course, the ability to speak English would be necessary. Language is a major component in the communication required in tourism and the unique culture is used as the main attraction in this village. This service focuses on culture-based English aimed at the young generation, also known as sekaa teruna-teruni in Tenganan Dauh Tukad. The learning method used is the communicative learning method. In addition, this activity is also supported by learning videos, PowerPoint, and material explanations. The result of this activity is that the participants who lack confidence and do not understand English well become confident and able to explain their culture in English well. Through communicative English teaching, participants' selfconfidence can be increased so they are not afraid to make mistakes in using English when dealing with tourists directly later.

Keywords: sekaa teruna-teruni, cultural English learning

Copyright (c) 2021 Ni Nyoman Kertiasih, I Nyoman Kardana, Anak Agung Istri Manik Warmadewi, Ni Luh Gede Mas Antartika Dewi Artana

$\triangle$ Corresponding author

Address : Universitas Warmadewa

ISSN 2721- 9224 (Media Cetak)

Email : nn.kertiasih@gmail.com

ISSN 2721- 9216 (Media Online)

DOI : https://doi.org/10.31004/abdidas.v2i5.416 
1065 Pengajaran Bahasa Inggris Komunikatif Berbasis Budaya kepada Sekaa Teruna-Teruni Desa Tenganan Dauh Tukad - Ni Nyoman Kertiasih, I Nyoman Kardana, Anak Agung Istri Manik Warmadewi, Ni Luh Gede Mas Antartika Dewi Artana

DOI: https://doi.org/10.31004/abdidas.v2i5.416

\section{PENDAHULUAN}

Salah satu desa di kecamatan Manggis, Karangasem, Bali yang dikenal memiliki tradisi unik sejak zaman dahulu ialah Desa Tenganan. Meskipun merupakan salah satu dari sekian banyak tempat yang dijadikan daya tarik wisata di Bali, tetapi desa ini tetap bertahan karena keistimewaannya. Desa Tenganan disebut sebagai salah satu desa yang masih mempertahankan tradisi serta kebudayaan nenek moyang yang dimiliki. Berbeda dengan desa lain di kota-kota besar yang kebanyakan sudah modern, desa ini tidak menolak adanya modernisasi tetapi tetap menjaga adat istiadat dan tradisi yang dianggap sakral bagi mereka. Adat istiadat dan tradisi itulah yang dijadikan pegangan bagi penduduk desa dan ternyata bagi wisatawan hal itu sangat menarik.

Membahas mengenai daya tarik Desa Tenganan tentu sangat banyak, salah satunya ialah kehidupan sehari-hari desa ini yang ditata oleh Awig-awig atau juga disebut dengan hukum adat Awig-awig yang pertama kali ditulis pada abad ke 11, dibandingkan dengan saat ini tentu mengalami perubahan yang tetap mengutamakan kelestarian adat dan budaya namun juga disesuaikan dengan kondisi penduduk atau krama saat ini (Puja et al., 2016). Unsur nama tenganan sebenarnya dimiliki oleh dua desa yang terletak pada kecamatan Manggis, Karangasem-Bali, yaitu Desa Tenganan Pegringsingan dan Desa Tenganan Dauh Tukad. Kegiatan pengabdian masyarakat ini dilakukan di Desa Tenganan Dauh Tukad.

Nama "Dauh Tukad" sendiri didapatkan karena desa ini memang berlokasi di bagian barat (dauh) dari sebuah sungai (sungai). Adat istiadat yang terdapat pada kedua desa ini bisa dikatakan "sama" secara garis besar, namun ada benang perbedaan yang cukup terlihat diantara kedua desa ini. Hal itu dikarenakan penduduk yang menghuni Desa Tenganan Dauh Tukad merupakan penduduk campuran Bali Aga dengan Majapahit pada zaman kerjaan dahulu kala. Sehingga tradisi yang dilahirkan juga terpeharuh oleh adat istiadar dari Majapahit itu sendiri, namun tidak mengurangi unsur eksistensi dari Bali Aga itu sendiri. Salah satu tradisi yang lahir dari proses penggabungan dua kebudayaan ini ini ialah "masabatan biu" atau perang pisang. Tradisi ini dilakukan setiap tahun saat pergantian ketua kelompok pemuda atau STT. (sekaa teruna-teruni) yang disebut Saya (Ardia et al., 2017).

Sekaa Teruna-teruni atau biasa disingkat dengan kata STT. merupakan sebutan lain bagi kelompok pemuda adat di Bali. STT. pada dasarnya berisi pemuda-pemudi yang berumur 17 tahun ke atas atau sesuai dengan peraturan dari STT. masing-masing dan belum menikah. Di Desa Tenganan Dauh Tukad ketua dari sekaa terunateruni ini disebut dengan Saya. Saya sendiri dipilih berdasarkan usia tertua atau paling senior yang tercatat ada di kelompok tersebut (Ardia et al., 2017). Sama halnya dengan ketua-ketua lain pada sebuah organisasi, Saya ditugaskan sebagai ketua sekaa teruna-teruni dan orang yang bertanggung jawab untuk mengumpulkan bahan-bahan yang digunakan untuk upacara Aci Ketiga dan Masabatan Biu yang bertempat di Bale Agung. Tentunya untuk tugas yang kedua seorang Saya 
1066 Pengajaran Bahasa Inggris Komunikatif Berbasis Budaya kepada Sekaa Teruna-Teruni Desa Tenganan Dauh Tukad - Ni Nyoman Kertiasih, I Nyoman Kardana, Anak Agung Istri Manik Warmadewi, Ni Luh Gede Mas Antartika Dewi Artana

DOI: https://doi.org/10.31004/abdidas.v2i5.416

tidak sendirian, Ia akan memberi tahu ibu-ibu desa dan mengajak anggota STT. untuk bekerja sama guna mengumpulkan bahan-bahan yang diperlukan di ladang yang dimiliki oleh Desa Tenganan Dauh Tukad maupun ladang yang dimiliki oleh penduduk.

Peranan Sekaa Teruna-teruni dapat dikatakan penting di setiap tempat termasuk di Desa Tenganan Dauh Tukad. Pemuda-pemudi dipercaya sebagai pemegang masa depan serta kelestarian budaya yang ada. Kebudayaan dalam Bahasa Inggris 'culture' berasal dari bahasa latin 'colera' yang berarti mengerjakan atau mengolah, sehingga kebudayaan atau culture dapat diterjemahkan menjadi daya atau usaha manusia untuk merubah alam (Nahak, 2019). Generasi muda selalu digambarkan sebagai calon-calon penerus yang akan menjalankan dan mewariskan tradisi dan kebudayaan yang ada kepada generasi berikutnya. Namun, seiring dengan dinamika penduduk dan globalisasi banyak pemuda-pemudi yang terkena imbasnya seperti mengalami proses urbanisasi.

Urbanisasi tidak bisa dihindari dan sejalan dengan adanya globalisasi serta modernisasi, tentunya urbanisasi juga terjadi di Desa Tenganan Dauh Tukad, dimana banyak anak-anak muda yang mencoba peruntungan dengan bekerja di kota pada saat muda dan kembali ke desa setelah usia lanjut. Hal itu disebabkan oleh banyak faktor seperti pemikiran bahwa pendapatan yang lebih besar jika bekerja di kota daripada di desa dan masih banyak lagi. Tapi saat ini pemuda-pemudi Desa Tenganan Dauh Tukad banyak yang sudah kembali ke desa mereka dikarenakan pandemi Covid-19 yang tidak kunjung usai. Banyak sektorsektor usaha yang ditutup karena sepi maupun gulung tikar. Sayangnya ketika kembali ke desa, sektor terbesar penyokong penghasilan penduduk yaitu pariwisata di Desa Tenganan Dauh Tukad juga terdampak oleh pandemi ini.

Tradisi dan kebudayaan yang dimiliki oleh masyarakat tentunya akan diwariskan kepada generasi muda yang akan memegang tongkat estafet tanggung jawab unuk kedepannya. Demikian juga di Desa Tenganan Dauh Tukad yang kaya akan tradisi unik, tentunya Sekaa Truna Truni (STT.) akan memegang peran penting untuk kelestarian tradisi mereka. Pentingnya pengetahuan yang terperinci mengenai segala bentuk tradisi dan kebudayan yang dimiliki akan membantu mereka dalam menjaga tradisi yang telah ada. Sayangnya banyak anak muda yang hanya tau tradisi tanpa tau makna ataupun asalusul dari tradisi tersebut dan biasanya hanya dijawab dengan tiga kata dalam bahasa bali yaitu "nak mule keto" atau "memang seperti itu".

Hal seperti itu juga terjadi di Desa Tenganan Dauh Tukad, hanya sebagian kecil dari pemudapemudi yang hapal dan tahu akan cerita mengenai kebudayaan mereka. Padahal cerita-cerita mengenai tradisi dan kebudayaan memiliki nilai jual tinggi dimata pariwisata. Selain memiliki kendala seperti diatas, kemampuan dan pemahanan akan bahasa Inggris ternyata juga belum merata bagi anggota sekaa teruna-teruni Desa Tenganan Dauh Tukad. Bahasa Inggris merupakan bahasa Internasional yang menjadi penghubung 
1067 Pengajaran Bahasa Inggris Komunikatif Berbasis Budaya kepada Sekaa Teruna-Teruni Desa Tenganan Dauh Tukad - Ni Nyoman Kertiasih, I Nyoman Kardana, Anak Agung Istri Manik Warmadewi, Ni Luh Gede Mas Antartika Dewi Artana

DOI: https://doi.org/10.31004/abdidas.v2i5.416

komunikasi paling dasar antara wisatawan dengan masyarakat di desa ini pada saat parwisata berjalan.

Maka dari itu kegiatan pengabdian kepada masyarakat ini dilakukan agar membantu sekaa teruna-teruni di Desa Tenganan Dauh Tukad untuk mempersiapkan diri dan mengasah kemampuan akan bahasa asing, terutama bahasa Inggris, dan budaya yang dimiliki. Diharapkan nantinya saat pariwisata kembali dibuka sumber daya masyarakat, terutama generasi muda, yang dimiliki oleh desa ini mampu bersaing dan mengembangkan segala potensi yang dimiliki oleh desa mereka.

\section{METODE}

Bertujuan untuk meningkatkan pemahaman sekaa teruna-teruni (generasi muda) di Desa Tenganan Dauh Tukad, Kecamatan Manggis, Karangasem, Bali, akan Bahasa Inggris dengan budaya yang dimiliki sebagai titik ukurnya maka metode pengajaran yang cocok digunakan dalam pengabdian ini adalah metode pengajaran dengan pendekatan komunikatif. Menurut Kodhijah pengajaran dengan pendekatan komunikatif dirancang agar dapat mengungkapkan pikiran dalam bahasa asing tanpa takut salah dan kesalahan adalah hal yang wajar (Khodijah \& Astuti, 2018). Sedangkan Harmer mengungkapkan bahwa pendekatan komunikatif merupakan cara pengajaran bahasa asing yang ditekankan pada interaksi dan mempelajari sebuah bahasa tidak bisa hanya diukur dari seberapa aspek bahasa itu tetapi juga dengan diupayakannya berbagai latihan sehingga kemampuan berbahasa dapat ditingkatkan (Fitriyani et al., 2020). Selain itu, Menurut Warmadewi, menerapkan pembelajaran Bahasa Inggris yang bersifat komunikatif membantu siswa merasa lebih senang dan materi yang diberikan dapat dipahami (Warmadewi et al., 2021).

Agar metode ini dapat berjalan dan berhasil sebagaimana mestinya maka dari itu metode ini akan ditekankan pada interaksi dua arah antara pengajar dengan peserta agar rasa percaya diri peserta dapat ditingkatkan sehingga peserta semakin menguasai dalam penuturkan bahasa asing, terutama Bahasa Inggris, tanpa takut salah. Metode pengajaran dengan pendekatan komunikatif yang dilaksanakan juga didukung dengan Materi pengajaran yang dipersiapkan, disampaikan melalui media power point, video singkat, dan tentunya dengan penjelasan yang bersifat aktif dan komunikatif dari pengajar. Posttest dan pre-test juga digunakan dalam kegiatan ini. Kedua latihan tersebut akan menunjukan pemahaman peserta khususnya pemuda-pemudi Desa Tenganan Dauh Tukad akan budaya yang dimiliki oleh desa mereka melalui Bahasa Inggris sebagai bahasa pengantar.

Selain itu pengajaran ini juga diisi dengan percakapan santai dan tanya-jawab lisan singkat agar peserta, pemuda-pemudi Desa Tenganan Dauh Tukad, merasa nyaman dan tidak canggung selama kegiatan ini berlangsung. Student center akan dijadikan acuan dalam menggunakan metode pembelajaran dengan pendekatan komunikatif ini, maka sebelum pengajaran dimulai rasa percaya 
1068 Pengajaran Bahasa Inggris Komunikatif Berbasis Budaya kepada Sekaa Teruna-Teruni Desa Tenganan Dauh Tukad - Ni Nyoman Kertiasih, I Nyoman Kardana, Anak Agung Istri Manik Warmadewi, Ni Luh Gede Mas Antartika Dewi Artana

DOI: https://doi.org/10.31004/abdidas.v2i5.416

diri dan rasa nyaman dari peserta akan sangat dibutuhkan dalam metode ini.

Dengan pemaparan seperti itu, maka kegiatan ini dilaksanakan selama 4 (empat) kali dalam satu bulan. Pertemuan pertama dijalankan pada tanggal 29 Mei 2021 dan kegiatan selanjutnya dilaksanakan seminggu sekali. Kegiatan pengabdian ini akan mengambil tempat di salah satu ruang kelas pada bangunan sekolah dasar di Desa Tenganan Dauh Tukad. Adapun metode evaluasi kegiatan yang digunakan antara lain membandingkan hasil pre-test dengan protest, penilaian secara langsung saat berdiskusi, dan keaktifan peserta selama kegiatan ini berlangsung.

\section{HASIL DAN PEMBAHASAN}

Kegiatan pengabdian masyarakat ini diadakan selama 4 (empat) kali pertemuan. Sebanyak 20 (dua puluh) orang, berusia 17-24 tahun, dari STT. Desa Tenganan Dauh Tukad mengikuti kegiatan ini. Pertemuan pertama diisi dengan perkenalan, tanya-jawab santai, serta posttest guna mengukur kemampuan Bahasa Inggris awal peserta yang berasal dari STT. Desa Tenganan Dauh Tukad. Post-testpada pertemuan pertama berisi 5 (lima) soal jawab singkat. Sayangnya terlihat masih banyak peserta, 10 orang, yang menggunakan mesin penerjemah online seperti Google Translate dan menyontek jawaban teman lainnya dalam menjawab soal. Saat ditanya kenapa menggunakan google translate dalam menjawab soal, jawaban yang diberikan tidak cukup mengagetkan yaitu "karena takut salah". Hal itu dapat diidentifikasi sebagai kurangnya rasa percaya diri akan kemampuan Bahasa Inggris yang dimiliki. Perkenalan dan tanya-jawab santai pada pertemuan ini berfungsi agar diciptakan suasana yang nyaman dan bersahabat bagi peserta agar proses pembelajaran dengan pendekatan komunikatif pada pertemuan selanjutnya dapat tercipta.

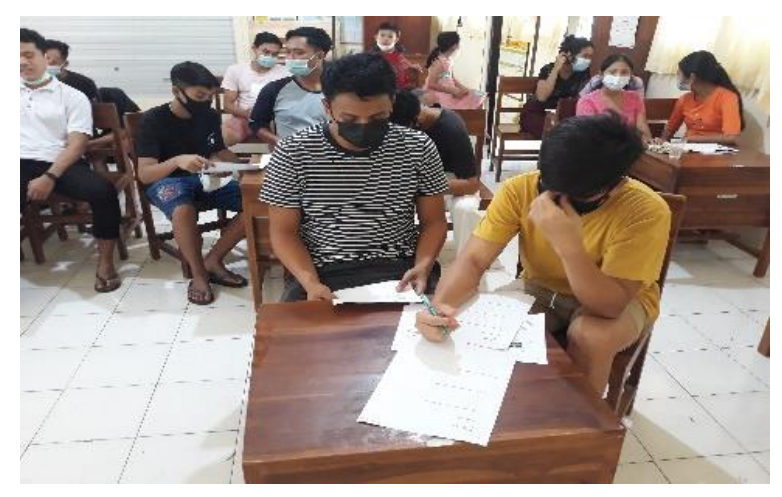

Gambar 1. Peserta Mengikuti Pre-test

Pertemuan selanjutnya diadakan seminggu kemudian yang difokuskan untuk penyampaian materi melalui powerpoint dan video tentang tipstips bagaimana mensiasati penyampaian suatu kebudayaan atau tradisi agar makna dan maksud dari kebudayaan itu tersampaikan dengan jelas kepada wisawatan. Pada pertemuan kali ini terlihat peserta sangat antusias dan fokus akan materi yang disampaikan. Setelah pertemuan kedua, diadakannya sebuah tanya-jawab singkat mengenai materi yang telah disampaikan agar tidak ada kekeliruan atau hal mengganjal di hati dan pikiran peserta. Beberapa peserta bertanya mengenai materi yang disampaikan, sedangkan beberapa lainnya berhasil menjawab pertanyaan yang ditanyakan oleh peserta lainnya. 
1069 Pengajaran Bahasa Inggris Komunikatif Berbasis Budaya kepada Sekaa Teruna-Teruni Desa Tenganan Dauh Tukad - Ni Nyoman Kertiasih, I Nyoman Kardana, Anak Agung Istri Manik Warmadewi, Ni Luh Gede Mas Antartika Dewi Artana

DOI: https://doi.org/10.31004/abdidas.v2i5.416

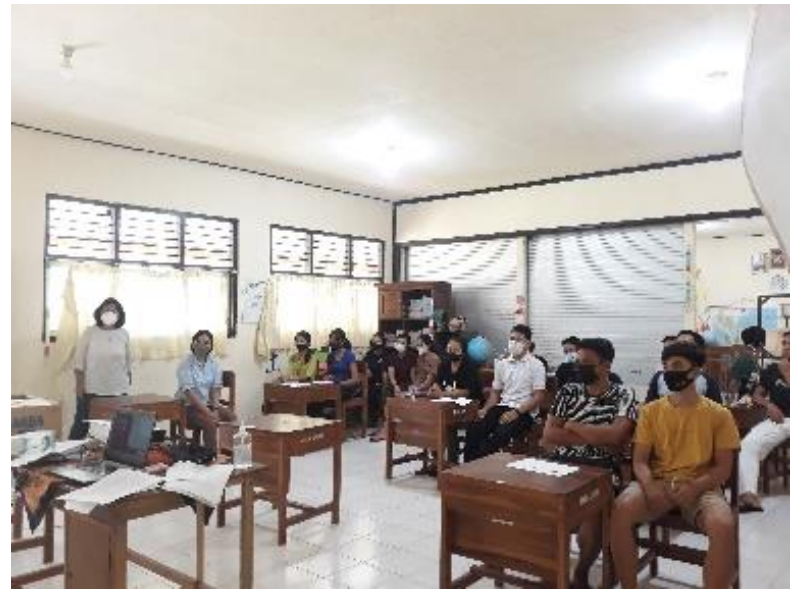

Gambar 2. Peserta sedang Menonton Video yang Diberikan

Fokus pada pertemuan ketiga adalah diskusi terbuka yang lebih luas mengenai materi pada pertemuan kedua. Peserta dipersilahkan menjelaskan kegiatan kebudayaan atau tradisi yang dimiliki dan diketahui seolah-olah sedang berhadapan dengan wisatawan. Dari 20 (dua puluh) peserta, sebanyak 16 (enam belas) peserta telah mampu menyusun penjelasan yang baik dan sesuai yang diberikan pada pertemuan sebelumnya. Tentunya saat dilakukan kegiatan diskusi terbuka ini para peserta saling mendukung guna menciptakan suasana yang tidak tegang sehingga tidak takut salah dalam pengucapan apapun. Tradisi atau kebudayan yang paling banyak dijelaskan oleh peserta ialah perang pandan dan perang pisang.

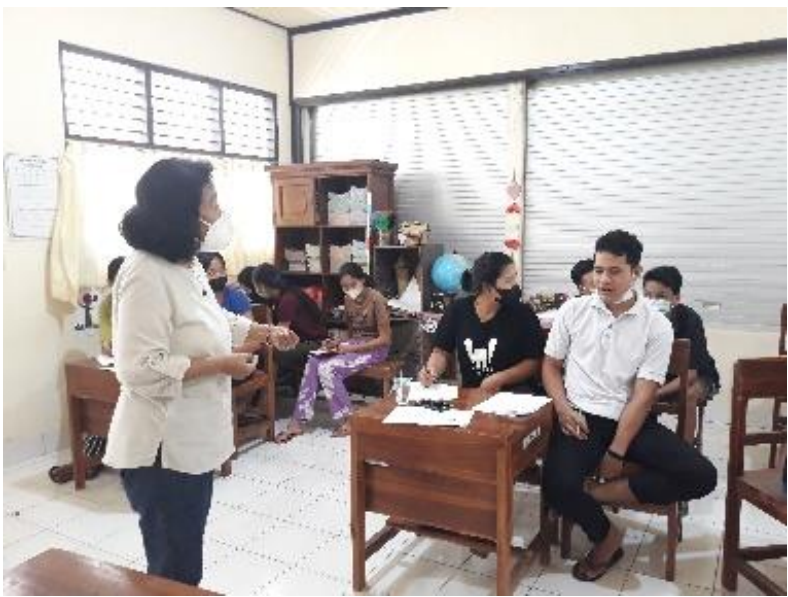

Gambar 3. Proses Pengarahan dari Pengajar

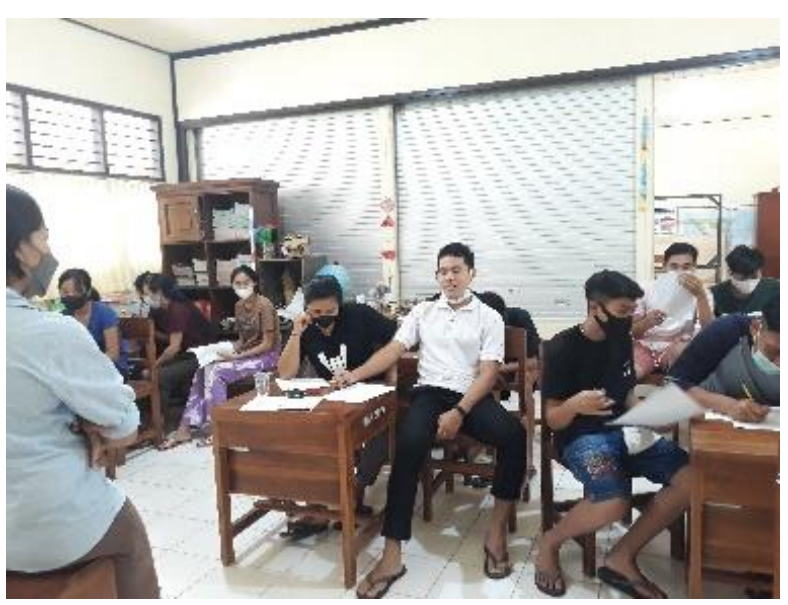

Gambar 4. Penjelasan dalam Bahasa Inggris dari Peserta

Pada pertemuan terakhir diadakan post-test yang berisi 5 (lima) soal jawab singkat mengenai kebudayaan dan tradisi Desa Tenganan Dauh Tukad, seperti penjelasan mengenai tardisi masabatan biu, aci usaba, dan lain-lain, tentunya dalam bahasa Inggris. Sebelum soal dijawab oleh peserta, kegiatan awal yang dilakukan adalah diskusi ringan mengenai asal-usul dari tardisi unik yang ada di Desa Tenganan Dauh Tukad dan halhal lain yang menarik di Desa Tenganan Dauh Tukad yang mungkin bisa dijadikan alternatif pariwisata selain tradisi yang dimiliki oleh desa 
1070 Pengajaran Bahasa Inggris Komunikatif Berbasis Budaya kepada Sekaa Teruna-Teruni Desa Tenganan Dauh Tukad - Ni Nyoman Kertiasih, I Nyoman Kardana, Anak Agung Istri Manik Warmadewi, Ni Luh Gede Mas Antartika Dewi Artana

DOI: https://doi.org/10.31004/abdidas.v2i5.416

ini. Kali ini tidak terlihat peserta yang menggunakan mesin penerjemah otomatis dan menyontek kepada teman lainnya. Lembar posttest yang terisi pun dijawab dengan kalimat yang kreatif dan inovatif oleh peserta dari STT. Desa Tenganan Dauh Tukad sehingga menarik untuk dibaca.

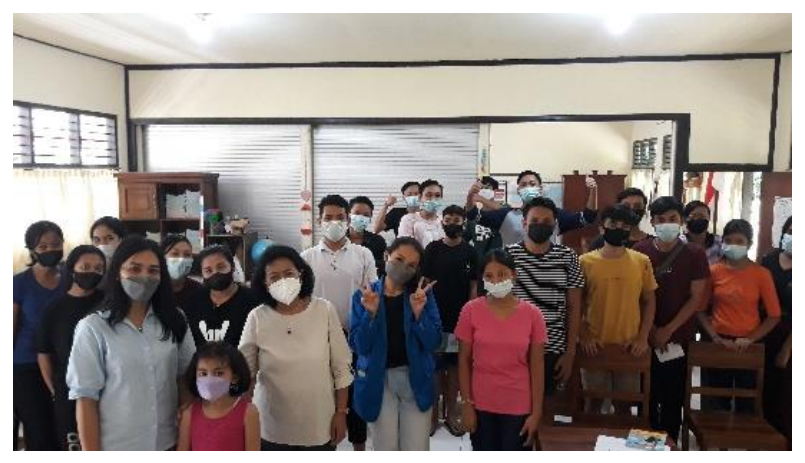

Gambar 5. Foto Peserta dan Pengajar

Generasi muda adalah generasi penerus yang memegang peranan penting dalam perkembangan masyarakat. Begitupula dengan sekaa teruna-teruni yang ada di Desa Tenganan Dauh Tukad. Terdiri atas pemuda-pemudi yang berusia 17-24 tahun tentunya akan menjadi sumber daya manusia yang berguna bagi desa mereka kedepannya. Pengetahuan bahasa asing, terutama bahasa Inggris merupakan jembatan penghubung antara desa ini dengan pariwisata. Maka diperlukan pemahaman yang cukup mengenai bahasa Inggris berbasis budaya agar dapat memajukan desa mereka.

Dari hasil kegiatan ini dapat disimpulkan bahwa terdapat peningkatan pemahaman bahasa Inggris berbasis budaya pada peserta, anggota sekaa teruna-teruni Desa Tenganan Dauh Tukad yang berjumlah 20 orang, yang dapat dilihat selama kegiatan ini dijalankan. Dari awal pertemuan terdapat $50 \%$ peserta yang mesih menggunakan mesin penerjemah dalam menyampaikan kalimat yang ingin disampaikan pada lembar pre-test, sedangkan pada pertemuan terakhir sebanyak $80 \%$ peserta telah mampu menyusun kalimat yang ingin disampaikan pada lembar pro-test tanpa menggunakan mesin penerjemah dan lebih percaya diri terhadap jawaban yang mereka berikan. Selain itu kemampuan peserta dalam menyampaikan kebudayaan atau tradisi yang dimiliki oleh desa mereka terbilang meningkat dikarenakan pemahaman dan rasa percaya diri yang telah tumbuh selama mengikuti kegiatan ini.

\section{SIMPULAN}

Setelah kegiatan dilakukan, dapat ditarik kesimpulan bahwa tujuan dari pengabdian kepada masyarakat, yaitu membantu sekaa teruna-teruni di Desa Tenganan Dauh Tukad untuk mempersiapkan diri dan mengasah kemampuan akan bahasa asing, terutama bahasa Inggris dan budaya yang dimiliki, telah tercapai. Selain itu dampak dan manfaat dari kegiatan ini nantinya dapat menambah nilai jual pariwisata Desa Tenganan Dauh Tukad kepada wisatawan, terutama wisatawan manca negara, karena sumber daya manusia, generasi muda atau sekaa teruna teruni, pada desa ini telah berhasil menambah pemahaman dan wawasan mereka mengenai Bahasa Inggris dan budaya yang dimiliki. 
1071 Pengajaran Bahasa Inggris Komunikatif Berbasis Budaya kepada Sekaa Teruna-Teruni Desa Tenganan Dauh Tukad - Ni Nyoman Kertiasih, I Nyoman Kardana, Anak Agung Istri Manik Warmadewi, Ni Luh Gede Mas Antartika Dewi Artana

DOI: https://doi.org/10.31004/abdidas.v2i5.416

\section{DAFTAR PUSTAKA}

Ardia, I. W., Suastika, I. M., \& Parimartha, I. G. (2017). Aci sasih ketiga dan masabatan biu di desa adat Tenganan Dauh Tukad (1st ed.). Pusat kajian Bali, Universitas Udayana. https://books.google.com/books/about/Aci_sa sih_ketiga_dan_masabatan_biu_di_de.html?i $\mathrm{d}=1$ szhzQEACAAJ

Fitriyani, Hasbi, M., \& Weda, S. (2020). Mengajar Bahasa Inggris Komunikatif. Prosiding Semnas LPPM Universitas Negeri Makasar, 602-604.

Khodijah, K., \& Astuti, M. (2018). Pendekatan Komunikatif Terhadap Keterampilan Berbicara Siswa Pelajaran Bahasa Inggris di MIN 1 Palembang. JIP: Jurnal Ilmiah PGMI, $3(2)$, 144-155.

https://doi.org/10.19109/jip.v3i2.1648

Nahak, H. M. . (2019). Upaya Melestarikan Budaya Indonesia Di Era Globalisasi. Jurnal Sosiologi Nusantara, 5(1), 65-76. https://doi.org/10.33369/jsn.5.1.65-76

Puja, I. N., Astariyani, N. L. G., Suparta, I. M., \& Siti, N. W. (2016, July). PEMBERDAYAAN POTENSI MASYARAKAT DALAM PENGEMBANGAN PARIWISATA BUDAYA DI DESA TENGANAN, KECAMATAN MANGGIS KABUPATEN KARANGASEM, BALI. Majalah Aplikasi Ipteks $\quad$ NGAYAH, $7(1), \quad 9$. https://media.neliti.com/media/publications/1 54673-ID-pemberdayaan-potensimasyarakat-dalam-pe.pdf

Warmadewi, A. A. I. M., Kardana, I. N., Raka, A. A. G., \& Artana, N. L. G. M. A. (2021). Pembelajaran Bahasa Inggris Komunikatif Berbasis Budaya. Jurnal Abdidas, 2(4), 743751.

https://doi.org/https://doi.org/10.31004/abdid as.v2i4.354 